\title{
Candidate insect vectors of apple proliferation in Northwest Spain
}

\author{
Marcos Miñarro ${ }^{1 *}$, Aitor Somoano , Aránzazu Moreno² and Rocío Rosa García
}

\begin{abstract}
The apple proliferation (AP) disease is spread mostly by two psyllids. Each species plays a predominant role as AP vector that changes regionally. Thus, there is an urgent need to identify the AP vectors in each region where the disease is present. This research aimed at identifying the psyllid community in apple orchards from Asturias (NW Spain) and studying their possible role in AP transmission. Yellow sticky traps were used to monitor psyllid community in five cider-apple orchards during 2 years. 3678 individuals belonging to 22 species were identified. We confirmed the presence of the two known vectors, Cacopsylla picta and Cacopsylla melanoneura, although they occurred in relatively low numbers (2.1 and $0.7 \%$ of total catches, respectively). Most collected psyllids are not supposed to use apple as host, and their occurrence is likely favoured by landscape structure and an insect-friendly management. Phytoplasma detection was performed by squash-capture real-time PCR. The pathogen was detected in six species (Cacopsylla crataegi, Cacopsylla mali, Ctenarytaina spatulata, Ctenarytaina eucalypti and the two known AP vectors). Based on abundance and AP-detection rate C. picta is likely the main species spreading AP in our region. However, the low density of the known vectors does not match the widespread and high tree damage level observed in Asturias. The discovery of other four psyllid species carrying the phytoplasma reveals that our knowledge on the potential vectors is limited and that more research is clearly needed to unravel the role of the psyllid fauna in disease transmission in our orchards.
\end{abstract}

Keywords: Cacopsylla melanoneura, Cacopsylla picta, Candidatus Phytoplasma mali, Ctenarytaina, Disease transmission, Psyllids, Trioza

\section{Background}

The apple proliferation (AP), induced by 'Candidatus Phytoplasma mali', is a serious disease that causes significant economic losses to apple growers. The multiplication and spread of phytoplasmas in apple trees is accompanied by the appearance of different symptoms (Kartte and Seemüller 1988; Zimmermann et al. 2015). The most characteristic symptom allowing a reliable identification of the infected plants is the witches' brooms caused by the loss of apical dominance of shoots and the proliferation of axillary buds. Other symptoms include foliar reddening, enlarged stipules, or smaller fruits with poor taste, what reduces significantly their marketability. The disease is widespread in Europe and neighbouring

\footnotetext{
*Correspondence: mminarro@serida.org

1 Servicio Regional de Investigación y Desarrollo Agroalimentario (SERIDA), Apdo. 13, E-33300 Villaviciosa, Asturias, Spain

Full list of author information is available at the end of the article
}

regions, with a highest economic impact occurring in Germany and northern Italy (Foissac and Wilson 2010). Annual losses due to AP in these two countries have been estimated in $€ 125$ million (Strauss 2009).

Apple proliferation symptoms have also been frequently observed in the last decade in apple orchards in Asturias, in the North coast of Spain. This region has long tradition in cider-making, and most of the 10,000 ha of apple orchards are cultivated almost exclusively to produce cider-apples. The majority of the surface devoted to apple production is occupied by traditional extensive orchards with big trees grown on seedling rootstocks. Since the early 1990s, an increasing percentage of these old orchards have been substituted by new semi-intensive ones with trees growing on semi-dwarfing rootstocks (Dapena et al. 2005). Those orchards are planted with selected local cultivars tolerant to several common apple diseases (scab, canker, powdery mildew). The use of pesticide in both situations is very low, even null. Sprays are 
mainly made with narrow-spectrum insecticides against the codling moth (Cydia pomonella L.) or the rosy apple aphid (Dysaphis plantaginea Passerini). Such situation of low pressure of pesticide use potentially allows high abundance and diversity of insects in orchards (Miñarro et al. 2005, 2009). The immersion of those orchards in an agricultural landscape characterized by a mosaic of small and different-land-use plots separated by hedgerows, as well as the occurrence of a permanent rich floral groundcover, also favour insect abundance and richness (Miñarro and Prida 2013; Rosa García and Miñarro 2014).

Phytoplasmas are obliged parasites which require a host plant as a reservoir of the disease and an insect host that contributes to spread the pathogen from an infected plant to a healthy one (Weintraub and Beanland 2006; Firrao et al. 2007; Alma et al. 2015). Since phytoplasmas are phloem-limited, only phloem-feeding insects can potentially acquire and transmit the pathogen (Weintraub and Beanland 2006). The available knowledge on the insect vectors of apple proliferation was summarized by Jarausch and Jarausch (2010). Different psyllid species belonging to the genus Cacopsylla (Hemiptera: Psyllidae) are considered the main vectors responsible for the transmission of European fruit tree phytoplasmas (Alma et al. 2015). Among them, Cacopsylla picta (Foerster) and Cacopsylla melanoneura (Foerster) are the known vectors of AP. Whereas C. picta is the known vector in Germany and NE Italy (Jarausch and Jarausch 2010), C. melanoneura was only confirmed as AP vector in Italy (Tedeschi and Alma 2004; Mayer et al. 2009; Tedeschi et al. 2012). Cacopsylla picta is monophagous on Malus spp., whereas C. melanoneura is oligophagous on Rosaceae such as Crataegus, Malus and Pyrus (Ossiannilsson 1992). Both species are univoltine and overwinter as an adult on conifers. Both generations, the overwintered and the new adults, can transmit AP (Tedeschi and Alma 2004; Jarausch et al. 2011), that is, C. picta and C. melanoneura are able to transmit the phytoplasma during the entire period when they are on apple trees.

'Candidatus Phytoplasma mali' has also been detected in other Cacopsylla species although their potential to transmit the disease is debatable (Tedeschi et al. 2009; Baric et al. 2010). Rosa García et al. (2014) also found the phytoplasma in two exotic eucalypt psyllid pests although their role as vectors remains unknown. Finally, the leafhopper Fieberiella florii (Stal) can also transmit AP in experimental conditions (Tedeschi and Alma 2006) although its role in the spread of AP is questionable given the low density of the species in apple orchards, at least in NW Italy (Tedeschi and Alma 2006).

There is still no treatment to cure AP-infected trees and thus the known possibilities to control the disease include preventing the pathogen spread by planting healthy material, uprooting diseased plants and acting against vectors (Baric et al. 2010). Regarding vector control, there is consequently an urgent need to identify which are the AP vectors in each region where the disease is present (Alma et al. 2015).

In Asturias, the available knowledge is limited to a preliminary survey focused on a single orchard (Laviña et al. 2011) which detected very low numbers of the known vectors (one specimen of C. picta and 12 of C. melanoneura), but no information was given on AP infection. In the Basque Country, close to Asturias, C. picta has been proposed as the main AP vector, according to its abundance and detection rate (Batlle et al. 2012). The widespread presence of AP symptoms in Asturias induced us to conduct a more-in-depth study on a larger number of orchards from different areas in the region to identify the psyllid community in the apple orchards of Asturias and to search for AP in the psyllids, with the main aim of analyzing their possible role in phytoplasma transmission.

\section{Methods \\ Site description}

Psyllid (superfamily Psylloidea) populations were monitored between February 2011 and December 2012 in five cider-apple orchards (Colunga, Siero, Nava, Villa 1 and Villa 2) located in Asturias, NW Spain (Fig. 1). A description of the experimental orchards is given in Table 1. At least seven different local cultivars were simultaneously grown in each orchard, as typically in cider orchards in this region. Asturias has a temperate oceanic climate with a fairly evenly spread rainfall over the year usually exceeding $1000 \mathrm{~mm}$. Meteorological data comprising daily rainfall as well as temperatures in the sampling period are shown in Rosa García et al. (2014). The occurrence of the AP disease was visually confirmed in all the orchards by the presence of witches' brooms, although the number of symptomatic trees was not recorded.

\section{Insect sampling and species identification}

Three yellow sticky traps $\left(200 \mathrm{~mm} \times 250 \mathrm{~mm}\right.$, Econex $\left.{ }^{\circledR}\right)$ were randomly installed in each site to identify and quantify the abundance/activity of adult psyllid fauna. The traps were hanged in the trees and replaced weekly. Psyllids were identified after examining morphological features, emphasizing in male and female terminalia, according to Hodkinson and White (1979) and Ossiannilsson (1992). The specimens were mostly alive when removed from the sticky traps and they were immediately transferred to $100 \%$ ethanol and stored at $5{ }^{\circ} \mathrm{C}$ until processed for AP detection.

\section{Detection of 'Candidatus Phytoplasma mali' in psyllids}

Phytoplasma detection in psyllids was performed by squash-capture real-time PCR. Single psyllids were 


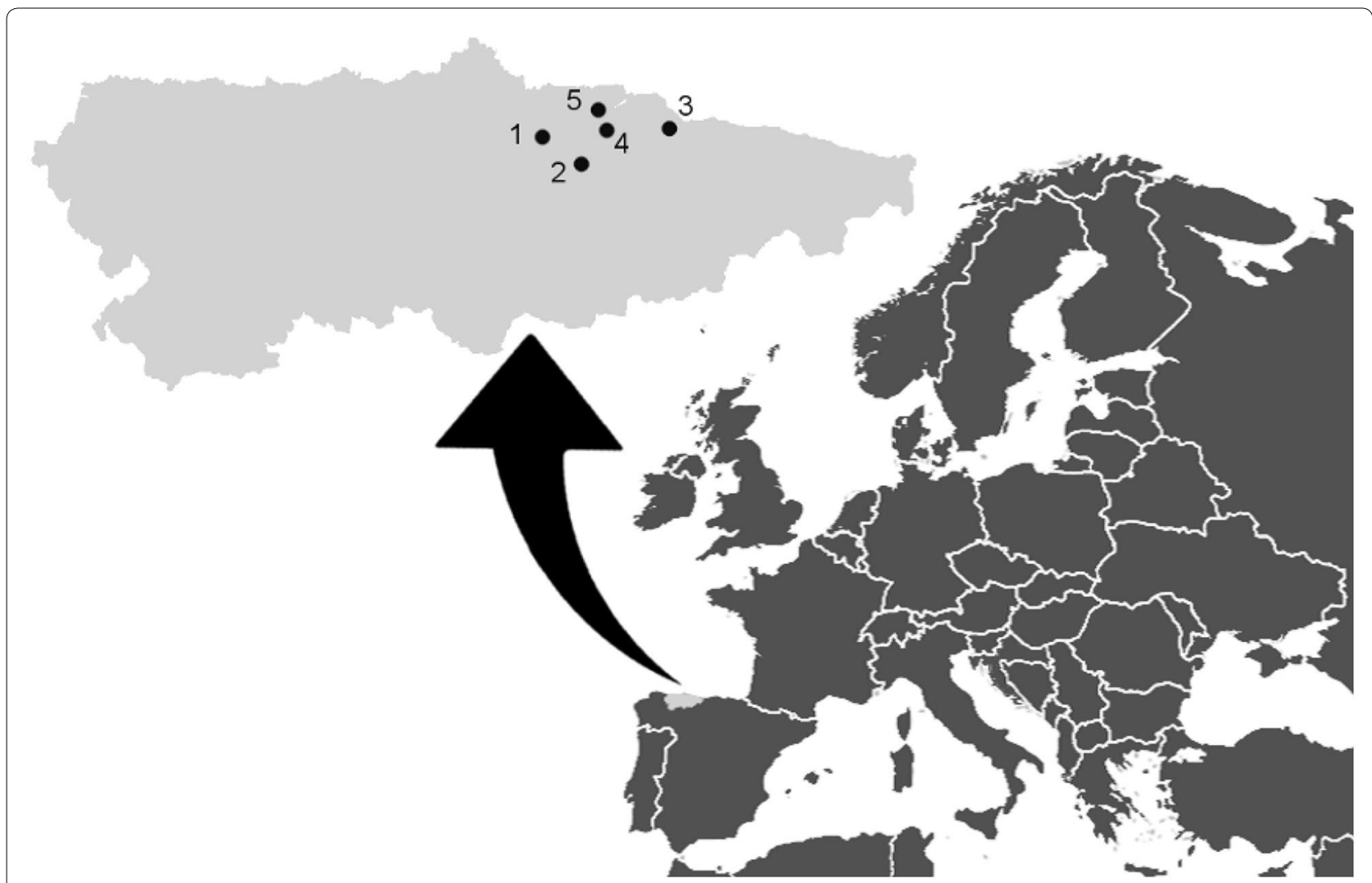

Fig. 1 Map indicating the location of the five orchards where psyllids were sampled. (1 Siero, 2 Nava, 3 Colunga, 4 Villa 1, 5 Villa 2)

Table 1 Orchard description (IFP- Integrated Fruit Production)

\begin{tabular}{llllcrl}
\hline Orchard & Orchard type & Guidelines & Year of plantation & Area $\left(\mathbf{m}^{\mathbf{2}}\right)$ & Altitude $(\mathbf{m})$ & Coordinates \\
\hline Siero & Semi-intensive & IFP & 1996 & 7600 & 333 & $N 43^{\circ} 26^{\prime} 03^{\prime \prime}-W 5^{\circ} 36^{\prime} 47^{\prime \prime}$ \\
Nava & High-stem trees & Organic & 1997 & 11,600 & 258 & $N 43^{\circ} 21^{\prime} 57^{\prime \prime}-W 5^{\circ} 29^{\prime} 31^{\prime}$ \\
Colunga & Semi-intensive & IFP & 1996 & 8000 & 40 & $N 43^{\circ} 28^{\prime} 52^{\prime \prime}-W 5^{\circ} 14^{\prime} 57^{\prime \prime}$ \\
Villa 1 & Semi-intensive & Organic & 1994 & 4200 & 2 & $N 43^{\circ} 28^{\prime} 44^{\prime \prime}-W 5^{\circ} 26^{\prime} 19^{\prime \prime}$ \\
Villa 2 & Semi-intensive & Organic & 1989 & 8100 & 2 & $N 43^{\circ} 28^{\prime} 34^{\prime \prime}-W 5^{\circ} 26^{\prime} 30^{\prime \prime}$ \\
\hline
\end{tabular}

squashed on paper with the rounded end of an Eppendorf tube. Pieces of squashed samples were inserted into Eppendorf tubes and $100 \mathrm{ml}$ of Triton X-100 $0.5 \%$ were added (Olmos et al. 1999), incubated at $95{ }^{\circ} \mathrm{C}$ for $10 \mathrm{~min}$, vortexed and placed on ice. Five microliters of each extract were directly used for the PCR assays. TaqMan assays for real-time PCR were performed in ABI Prism 7300 Sequence Detection System software (Applied Biosystems) according to Aldaghi et al. (2007) with a few modifications. The reaction cocktail contained $2 \times$ TaqMan $^{\circledR}$ Gene Expression Master Mix (Applied Biosystems), $10 \mu \mathrm{M}$ primer qAP-16S-F (5' CGA ACG GGT GAG TAA CAC GTA A $3^{\prime}$ ), $10 \mu \mathrm{M}$ primer qAP-16S-R (5' CCA GTC TTA GCA GTC GTT TCC A $\left.3^{\prime}\right), 5 \mu \mathrm{M}$ TaqMan probe APMGB (5' FAM-CTG CCT CTT AGA CGA GG MGB 3') and $5 \mu \mathrm{l}$ of extracted DNA targets from the immobilized samples. Real-time PCR protocol consisted in an initial denaturation phase of $10 \mathrm{~min}$ at $95{ }^{\circ} \mathrm{C}$ followed by 45 cycles of amplification $\left(95^{\circ} \mathrm{C}\right.$ for $15 \mathrm{~s}$ and $64{ }^{\circ} \mathrm{C}$ for $1 \mathrm{~min}$ ). Data acquisition and analysis were performed with the ABI Prism 7300 software. Each sample was analyzed as two technical replicates to corroborate the positive results. 


\section{Data analyses}

Kruskal-Wallis tests were used to evaluate the amongsite differences in psyllid abundance. $X^{2}$-tests were used to compare the number of males and females in each species. $X^{2}$-tests were also used to compare betweenyear differences in psyllid abundance. Statistical analyses were performed with SPSS (IBM SPSS statistics version 19.0.0).

\section{Results}

\section{Psyllid community in apple orchards}

A total of 3678 individuals belonging to 22 species were identified (Table 2). The number of species per orchard ranged from 15 to 19 (Table 2). Ctenarytaina spatulata Taylor and Ctenarytaina eucalypti (Maskell) were respectively the first (59.7\% of total catches) and the fifth (2.8\%) most abundant species. The results concerning these two species have been previously reported as a singular case because they are exotic pests whose common hosts were supposedly limited to Eucalyptus species and this was the first time in which they were recorded feeding on apple (Rosa García et al. 2014). Therefore, results regarding these species are not repeated in the present paper. In addition, only results for species with more than 25 specimens are shown here.

Among the rest of psyllids, a total of 12 Cacopsylla species were collected. Apple-dwelling Cacopsylla mali (Schmidberger) was the most abundant one $(19.5 \%$ of total catches), although it was mainly recorded in one orchard (95.8\% of catches) and it was absent in two. Cacopsylla visci (Curtis) (4.5\%) and Cacopsylla saliceti (Foerster) (4.2\%) followed $C$. mali in abundance. The two known AP vectors, $C$. picta and $C$. melanoneura were detected in all the orchards, although their

Table 2 Abundance of psyllid species in each apple orchard and year

\begin{tabular}{|c|c|c|c|c|c|c|c|c|c|c|c|}
\hline \multirow[t]{2}{*}{ Species } & \multirow[t]{2}{*}{ Total } & \multirow[t]{2}{*}{$\%$} & \multicolumn{5}{|l|}{ Orchard } & \multicolumn{2}{|l|}{ Year $^{a}$} & \multicolumn{2}{|l|}{ Effects $^{b}$} \\
\hline & & & Colunga & Nava & Siero & Villa 1 & Villa 2 & 2011 & 2012 & Orchard & Year \\
\hline Ctenarytania spatulata & 2195 & 59.7 & 595 & 217 & 555 & 429 & 399 & 1289 & 906 & $* * *$ & $* * *$ \\
\hline Cacopsylla mali & 717 & 19.5 & - & 29 & 687 & 1 & - & 445 & 272 & $* * *$ & $* * *$ \\
\hline Cacopsylla visci & 164 & 4.5 & 10 & 9 & 118 & 18 & 9 & 91 & 73 & $* * *$ & ns \\
\hline Cacopsylla saliceti & 153 & 4.2 & 10 & 20 & 100 & 11 & 12 & 133 & 20 & ns & $* * *$ \\
\hline Ctenarytania eucalypti & 104 & 2.8 & 7 & 54 & 28 & 8 & 7 & 79 & 25 & $*$ & $* * *$ \\
\hline Trioza urticae & 94 & 2.6 & 23 & 3 & 25 & 19 & 24 & 44 & 50 & * & ns \\
\hline Cacopsylla picta & 79 & 2.1 & 7 & 31 & 24 & 3 & 14 & 30 & 49 & $* *$ & $*$ \\
\hline Trioza remota & 49 & 1.3 & 2 & 11 & 18 & 16 & 2 & 12 & 37 & $* * *$ & $* * *$ \\
\hline Cacopsylla melanoneura & 27 & 0.7 & 10 & 4 & 8 & 2 & 3 & 13 & 14 & ns & ns \\
\hline Trioza alacris & 18 & 0.5 & 7 & - & 7 & 3 & 1 & 3 & 15 & * & $* *$ \\
\hline Cacopsylla spp. & 17 & 0.5 & 6 & 1 & 8 & 1 & 1 & 10 & 7 & ns & ns \\
\hline Aphalara polygoni & 12 & 0.3 & 1 & 2 & 4 & 3 & 2 & 9 & 3 & ns & ns \\
\hline Homotoma ficus & 10 & 0.3 & 5 & - & 4 & 1 & - & 8 & 2 & * & ns \\
\hline Cacopsylla crataegi & 8 & 0.2 & - & 7 & 1 & - & - & 2 & 6 & $* *$ & ns \\
\hline Cacopsylla pyricola & 8 & 0.2 & 1 & 2 & 4 & 1 & - & 5 & 3 & ns & ns \\
\hline Cacopsylla pulchra & 7 & 0.2 & 2 & 1 & 3 & - & 1 & 4 & 3 & ns & ns \\
\hline Cacopsylla pruni & 5 & 0.1 & 1 & 2 & 1 & - & 1 & - & 5 & ns & * \\
\hline Acizzia acaciaebaileyanae & 4 & 0.1 & - & 1 & 3 & - & - & 3 & 1 & ns & ns \\
\hline Trioza flavipennis & 3 & 0.1 & - & - & - & 2 & 1 & 3 & - & ns & $\mathrm{ns}$ \\
\hline Cacopsylla sorbi & 2 & 0.1 & 1 & - & - & - & 1 & - & 2 & ns & ns \\
\hline Cacopsylla affinis & 1 & 0 & - & - & - & 1 & - & 1 & - & ns & $\mathrm{ns}$ \\
\hline Psyllopsis fraxini & 1 & 0 & - & - & 1 & - & - & - & 1 & ns & $\mathrm{ns}$ \\
\hline Total & 3678 & & 688 & 394 & 1599 & 519 & 478 & 2184 & 1494 & $* * *$ & $* * *$ \\
\hline$\%$ & & & 18.7 & 10.7 & 43.5 & 14.1 & 13 & 59.4 & 40.6 & & \\
\hline \# of species & 22 & & 16 & 16 & 19 & 16 & 15 & 19 & 20 & & \\
\hline
\end{tabular}

Differences in abundance due to orchards and years are indicated by asterisks

a 45 weeks in 2011 and 51 weeks in 2012

b ns-no significant

${ }^{*} \mathrm{p}<0.05,{ }^{* *} \mathrm{p}<0.01,{ }^{* * *} \mathrm{p}<0.001$ 
relative occurrence was low (2.1 and $0.7 \%$ of total catches, respectively). Two Trioza species, T. urticae (L.) (2.6\%) and T. remota Foerster (1.3\%) were also among the psyllid species with more than 25 specimens.

There were significant differences among orchards in total psyllid abundance as well as in the abundance of all of the most abundant psyllids but one, C. saliceti (Table 2). The total psyllid catches were higher in 2011 than in 2012 despite the sampling periods lasted 45 weeks in 2011 and 51 weeks in 2012 (Table 2). The catches of four of the five most abundant species were also higher in 2011 than in the next year (Table 2).

Only the catches of the two most abundant species were sex-biased: $C$. spatulata catches were female-biased (60.7\% of females; $\left.x^{2}=100.21 ; \mathrm{p}<0.001\right)$ and $C$. mali catches were male-biased ( $73.5 \%$ of males; $\chi^{2}=158.36$; $\mathrm{p}<0.001)$.

Population dynamics of the most abundant psyllids as well as those carrying phytoplasma are shown in Fig. 2. Most of those species showed a rather similar phenological pattern in both years. Cacopsylla mali was detected from spring to autumn, reaching a density peak in midsummer. Curiously, only males contributed to that peak. Cacopsylla visci was detected almost continuously, although a small density peak was observed in spring. Cacopsylla saliceti only showed a clear density peak in the spring of 2011, whereas such peak was more subtle in 2012 due to the lower catches. Cacopsylla picta showed two peaks every year, one in March-April and other around June. Cacopsylla melanoneura appeared at the end of winter, peaking early in the spring. The catches of Cacopsylla crataegi (Schrank) were low and occurred in spring, from February to May. Finally, neither a clear nor a repetitive pattern was appreciated in the case of the most abundant Trioza species.

\section{Detection of 'Candidatus Phytoplasma mali' in psyllids}

Phytoplasma detection was performed for the eight most abundant species and the presence of the pathogen was confirmed in six of them (Table 3). The highest detection rate (10.0-16.7 \%) was found in four Cacopsylla species (C. crataegi, C. picta, C. melanoneura and C. mali). On the contrary, the detection rate in the two exotic Ctenarytaina species was below $3 \%$. AP-positive males were detected in all the six species whereas positive females were detected only in two of them (Table 3 ). The global detection rate was higher for males (7.1\%) than for females $(2.1 \%)$. The spatial distribution of the AP-positive specimens is unclear because the abundance and consequently the number of evaluated specimens varied widely among sites (Tables 2 and 3). Nevertheless, AP-positive individuals were detected in all the orchards, ranging from 2.8 to $6.7 \%$ (Table 3 ). In addition, in one orchard four AP positive species were confirmed whereas in three orchards only one AP-positive species was detected (Table 3). AP-positive individuals were found from March to October, depending on the species, being globally higher in March and from June onwards (Table 4).

\section{Discussion}

The present research provides the first comprehensive approach to the psyllid fauna in apple orchards in Asturias, NW Spain, and allowed us to identify the species carrying the phytoplasma, which are consequently candidates to be AP vectors in this region. Among them, we confirmed the presence of C. picta and C. melanoneura, the two known AP vectors in other European regions (Jarausch and Jarausch 2010).

Cacopsylla picta and C. melanoneura use apple as primary hosts, although $C$. melanoneura can also reproduce on hawthorn and pear, and both species use conifers for overwintering (Ossiannilsson 1992). The phenology of both psyllids is synchronized with apple phenology, and it is probably mediated by temperature (Tedeschi et al. 2012): at the end of winter re-migrant adults move from the overwintering sites to apple trees to reproduce and lay eggs before or coinciding with bud break (Tedeschi et al. 2002, 2012; Jarausch et al. 2011). The new generation leaves the host plant in summer and migrates to the overwintering hosts. In the current study, the adult $C$. melanoneura arrived to and left the apple tree earlier than C. picta did. This trend matches the previous knowledge for the phenology of these species (Tedeschi et al. 2002, 2012; Jarausch et al. 2011).

The actual risk of transmission of a pathogen to a crop under field conditions could be estimated by the vector intensity (Irwin and Ruesink 1986), which is determined as the final product of two factors: the vector activity (number of insects visiting the crop) and the vector propensity (probability of a vector transmitting a pathogen under field conditions). The number of insects carrying the pathogen can also influence the second factor. Accordingly, each species seems to play a predominant role in different regions: whereas $C$. picta is the main AP vector in Germany and NE Italy, $C$. melanoneura is the main vector in NW Italy (Jarausch and Jarausch 2010 and references therein). Nevertheless, Tedeschi et al. (2012) recently demonstrated the importance of $C$. melanoneura in spreading AP also in NE Italy. In our case, both species were collected in all the study sites. Cacopsylla picta catches were three times those of C. melanoneura, being clearly higher in three of the orchards, contrarily to the previous observation of Laviña et al. (2011) in one site located also in Asturias, who reported one specimen of C. picta and 12 of C. melanoneura in the sampled 


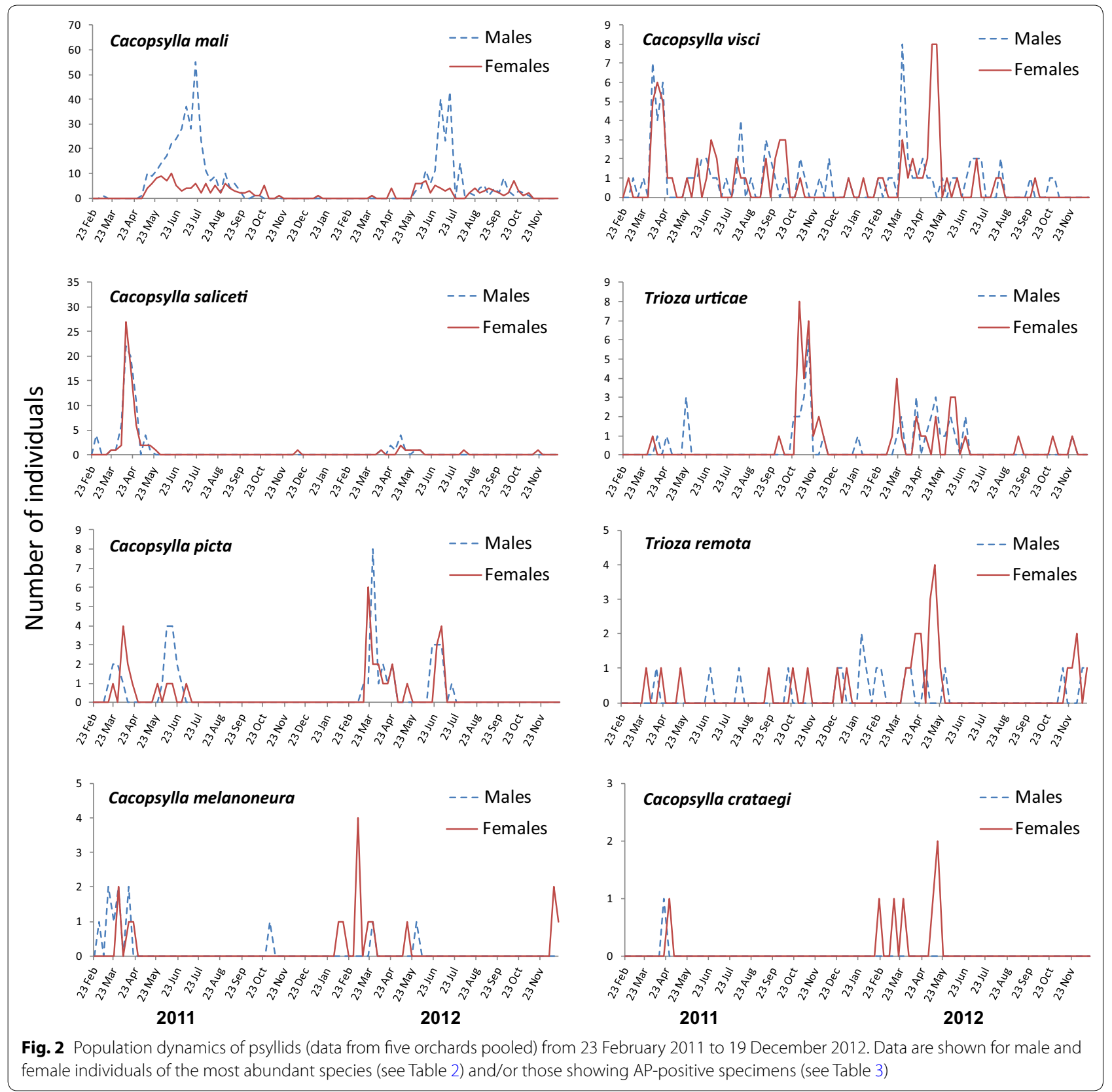

orchard. In any case, the abundance of these species in our orchards was very low compared to the other psyllid species but it also differs from other studies (e.g. Tedeschi et al. 2003; Jarausch et al. 2009). In our two-year sampling we recorded only a total of 79 and 27 specimens of C. picta and C. melanoneura, respectively. For instance, Tedeschi et al. (2012) recorded up to eight specimens of C. melanoneura per branch at a single sampling event using a beating method.

Both psyllids are highly efficient vectors of AP and they can transmit the phytoplasma during the entire period when they are on apple trees, although transmission trials confirmed that the overwintered generation would be more effective than the new adults (Tedeschi and Alma 2004; Jarausch et al. 2011). Phytoplasma acquired by the new generation could have a very low titre and maybe the latency period is not yet completed before migration to conifers (Tedeschi et al. 2003). This would explain such generation differences as well as the highest detection rate in the overwintering generation. For C. melanoneura, Tedeschi et al. (2003) found 2.8-3.6 \% AP-positive specimens in the overwintering generation versus 
Table 3 Results of phytoplasma detection [no positive detections/total number of analyzed individuals (\%)] for the most abundant species according to sex and orchard

\begin{tabular}{|c|c|c|c|c|c|c|c|c|c|}
\hline \multirow[t]{2}{*}{ Species } & \multirow[t]{2}{*}{ Total } & \multirow{2}{*}{$\begin{array}{l}\mathrm{Ct}^{*}(\operatorname{mean} \pm \mathrm{SE})[\mathrm{max}- \\
\mathrm{min}]\end{array}$} & \multicolumn{2}{|l|}{ Sex } & \multicolumn{5}{|l|}{ Orchard } \\
\hline & & & Male & Female & Colunga & Nava & Siero & Villa 1 & Villa 2 \\
\hline Cacopsylla crataegi & $1 / 6(16.7)$ & 34.95 & $1 / 1(100.0)$ & $0 / 5$ & - & $1 / 5(20.0)$ & $0 / 1$ & - & - \\
\hline Cacopsylla picta & $9 / 68(13.2)$ & $28.44 \pm 1.47$ & $7 / 37(18.9)$ & $2 / 30(6.7)$ & $0 / 6$ & $4 / 30(13.3)$ & 3/19 (15.8) & $0 / 1$ & $2 / 12(16.7)$ \\
\hline Cacopsylla melanoneura & $1 / 10(10.0)$ & {$[23-35] 33.57$} & $1 / 2(50.0)$ & $0 / 8$ & $0 / 1$ & 1/3 (33.3) & $0 / 3$ & $0 / 2$ & $0 / 1$ \\
\hline Cacopsylla mali & $6 / 60(10.0)$ & $34.35 \pm 0.22[34-35]$ & $4 / 37(10.8)$ & $2 / 23(8.7)$ & - & $0 / 6$ & $6 / 54(11.1)$ & - & - \\
\hline Ctenarytaina spatulata & $2 / 75(2.7)$ & $32.00 \pm 1.00[31-33]$ & $2 / 38(5.3)$ & $0 / 37$ & $0 / 13$ & $1 / 11(9.1)$ & $0 / 20$ & $1 / 18(5.6)$ & $0 / 13$ \\
\hline Ctenarytaina eucalypti & $1 / 73(1.4)$ & 35.02 & $1 / 36(2.8)$ & $0 / 37$ & $1 / 6(16.7)$ & $0 / 36$ & $0 / 19$ & $0 / 7$ & $0 / 5$ \\
\hline Cacopsylla saliceti & $0 / 60$ & - & $0 / 40$ & $0 / 20$ & $0 / 6$ & $0 / 10$ & $0 / 33$ & $0 / 4$ & $0 / 7$ \\
\hline Cacopsylla visci & $0 / 60$ & - & $0 / 33$ & $0 / 27$ & $0 / 4$ & $0 / 3$ & $0 / 48$ & $0 / 2$ & $0 / 3$ \\
\hline Total & $20 / 412(4.9)$ & & $16 / 224(7.1)$ & $4 / 187(2.1)$ & $1 / 36(2.8)$ & $7 / 104(6.7)$ & $9 / 197(4.6)$ & $1 / 34(2.9)$ & $2 / 41(4.9)$ \\
\hline
\end{tabular}

Positive results in italics

$\mathrm{Ct}^{*}$ mean threshold cycle by species

Table 4 Results of phytoplasma detection ( $n^{\circ}$ positive detections /total of analyzed individuals) according to the month

\begin{tabular}{|c|c|c|c|c|c|c|c|c|c|c|c|c|}
\hline Species & Jan & Feb & Mar & Apr & May & Jun & Jul & Aug & Sep & Oct & Nov & Dec \\
\hline Cacopsylla crataegi & - & - & $0 / 1$ & $1 / 2$ & $0 / 3$ & - & - & - & - & - & - & - \\
\hline Cacopsylla picta & - & - & $6 / 23$ & $1 / 16$ & $0 / 3$ & $1 / 22$ & $1 / 4$ & - & - & - & - & - \\
\hline Cacopsylla melanoneura & - & $0 / 2$ & $1 / 6$ & $0 / 1$ & $0 / 1$ & - & - & - & - & - & - & - \\
\hline Cacopsylla mali & - & - & - & - & $0 / 5$ & $3 / 15$ & $0 / 14$ & $1 / 10$ & $1 / 10$ & $1 / 5$ & $0 / 1$ & - \\
\hline Ctenarytaina spatulata & $0 / 5$ & $0 / 6$ & $0 / 5$ & $0 / 7$ & $0 / 8$ & $1 / 6$ & $0 / 1$ & $1 / 9$ & $0 / 6$ & $0 / 10$ & $0 / 8$ & $0 / 4$ \\
\hline Ctenarytaina eucalypti & $0 / 1$ & - & $0 / 7$ & $0 / 28$ & $1 / 18$ & $0 / 1$ & - & - & - & - & $0 / 10$ & $0 / 8$ \\
\hline Cacopsylla saliceti & - & - & $0 / 1$ & $0 / 43$ & $0 / 15$ & - & - & $0 / 1$ & - & - & - & - \\
\hline Cacopsylla visci & $0 / 3$ & $0 / 2$ & $0 / 2$ & $0 / 8$ & $0 / 13$ & $0 / 10$ & $0 / 3$ & $0 / 6$ & $0 / 5$ & $0 / 5$ & $0 / 1$ & $0 / 2$ \\
\hline Total & $0 / 9$ & $0 / 10$ & $7 / 45$ & $2 / 105$ & $1 / 66$ & $5 / 54$ & $1 / 22$ & $2 / 26$ & $1 / 21$ & $1 / 20$ & $0 / 20$ & $0 / 14$ \\
\hline$\%$ & 0 & 0 & 15.6 & 1.9 & 1.5 & 9.3 & 4.5 & 7.7 & 4.8 & 5.0 & 0 & 0 \\
\hline
\end{tabular}

Positive results in italics

$0-0.8 \%$ in the spring one. The low captures of C. melanoneura prevented a similar comparison in our study. Otherwise, we observed a similar pattern in C. picta: 7 of $39(17.9 \%)$ of the specimens collected in March and April were infected versus only 2 of 26 (7.7\%) specimens from June to July. On the other hand, Jarausch et al. (2011) reported a similar phytoplasma titre along time in overwintering C. picta, confirming that the phytoplasma overwinters in the insect.

Our AP detection rate for C. picta (13.2\%) is similar to that previously obtained in other European regions [ $\approx 10 \%$ in a German-Swiss-Italian study (Jarausch et al. 2011) or $11.1 \%$ in NE Italy (Baric et al. 2010)]. On the contrary, our AP-detection rate for $C$. melanoneura $(10.0 \%)$ is markedly higher than the one reported in other regions where this species is not an AP vector [0.09 \% in Germany (Mayer et al. 2009) or $0.6 \%$ in NE Italy (Baric et al. 2010)] but also higher than where $C$. melanoneura transmits the phytoplasma [3.6-6.5\% for the overwintering generation and less than $0.8 \%$ in the spring one in NW and NE Italy (Tedeschi et al. 2003, 2012)].

High infection rates have been correlated with transmission ability both at specific and at generation level (Tedeschi and Alma 2004; Mayer et al. 2009; Jarausch et al. 2011). Accordingly, both species, C. picta and $C$. melanoneura, might be able to transmit AP in NW Spain, but transmission trials are needed to confirm it (e.g. Tedeschi and Alma 2004; Jarausch et al. 2011).

'Candidatus Phytoplasma mali' is a phloem-restricted pathogen and thus insects feeding on phloem could acquire the phytoplasma. AP-positive individuals have been reported for other psyllids: $C$. mali (Baric et al. 2010) and Cacopsylla peregrina (Foerster) (Tedeschi et al. 2009), as well as for aphids (Cainelli et al. 2007). However, transmission has not been proved for these species. We have detected AP-positive specimens in C. mali and also in C. crataegi. To our knowledge this is the first time that AP was detected for C. crataegi. Finally, as previously reported (Rosa García et al. 2014) we found positive 
specimens in the two exotic psyllids, C. spatulata and C. eucalypti. These two eucalypt pests were present in all the orchards and were abundant, especially the former, although their infection rate was low $(<3 \%)$ in both cases. Cacopsylla mali was also abundant and showed important infection rates (10\%), but it was not detected in all orchards. Cacopsylla crataegi showed the highest detection rate (16.7 \%) albeit its density was very low (eight specimens in just two orchards).

In any case, the occurrence of AP-positive specimens indicates that all these species reach the phloem of infected trees, although the acquisition of a phytoplasma does not necessarily mean that the insect is a vector. As a previous step to transmission, the phytoplasma should multiply itself inside the insect and reach the salivary glands to be transmitted in a new feeding event on a healthy plant (Weintraub and Beanland 2006). Therefore, experimental transmission trials are required again to prove that a phytoplasma-positive insect is a vector. As a first step before transmission trials, quantitative real-time PCR is a useful tool to have a first indication between non-vectors, which have just acquired the phytoplasma by sucking, and real vectors which have multiplied the phytoplasma (Jarausch and Jarausch 2010). Furthermore, in the field, phloem-restricted pathogens are transmitted efficiently only by colonizing species, and from an epidemiological point of view, the transmission of a persistent phloem-restricted plant pathogen by non-colonizing species (most species in our study) is very unlikely to occur (Irwin et al. 2007).

A thorough and extensive sampling (7 years, 50 orchards) in Germany, France and Switzerland reported 25 psyllid species inhabiting apple orchards (Jarausch et al. 2009). With a considerably lower effort (2 years, 5 orchards) we collected 22 species, varying the number of species per site between 15 and 19. Such a high richness is likely a consequence of the low pesticide input in our cider-apple orchards as well as the high plant richness in the orchards and their surroundings (Miñarro and Prida 2013; Rosa García and Miñarro 2014), since most of the collected psyllids have not apple among their hosts (Ossiannilsson 1992; Jarausch et al. 2009). In fact, only three species, C. mali, C. picta and C. melanoneura, have apple as a host (Ossiannilsson 1992). They are the most abundant psyllids in apple orchards (Jarausch et al. 2009), although not in our study. The occurrence and density of the Ctenarytaina species are easily explained by the wide distribution of eucalypt crops in the surroundings of the orchards (Rosa García et al. 2014). The third most abundant species, C. visci, has mistletoe (Viscum album L.) as host (Hansen and Hodkinson 2006), and this parasitic plant frequently grows on apple in our region. The other abundant species, C. saliceti, T. urticae and T. remota
Foerster, live on Salix, Urtica and Quercus, respectively (Ossiannilsson 1992), all of which can be either present in the orchards or in nearby habitats.

Since there is no therapy available to cure infected trees, disease control should rely on prevention. Therefore, monitoring the vectors should be a crucial step for control, and this could be implemented with forecasting models (Tedeschi et al. 2012). However, the high species richness detected in our orchards, as well as the relative low densities of the known vectors, impose serious constraints to reliably monitor the presence of vectors in the orchards as morphological identification is problematic and time-consuming. Fortunately, recently developed molecular tools allow a reliable identification of Cacopsylla species inhabiting orchards (Oettl and Schlink 2015), facilitating monitoring. On the other hand, chemical control of vectors in our region is difficult. First, because of the difficulty to monitor such low vector densities. And second because the management of most potential pests in our orchards is based on biological control (e.g. Miñarro et al. 2005) and the use of broad-spectrum insecticides against vectors would probably disrupt such control increasing the appearance of secondary pests. Alternative methods, such as mass trapping with phytopathogen-induced plant alomones (Eben and Gross 2013), would be welcome.

\section{Conclusion}

We report new data related to new epidemiological situations as a result of the particular environmental situations in apple production in NW Spain. Our cider-apple orchards are inhabited by an abundant and rich psyllid community, including the two so far known AP-vectors as well as exotic species and others which are not supposed to use apple as host. Total captures of C. picta (79) were clearly higher than those of C. melanoneura (27) and, although both detection rates were rather similar (around $10 \%$ ), rate of C. picta is more significant because the percentage of positive specimens was more regular among orchards. Thus, C. picta is likely the putative vector in our region, although a contribution of C. melanoneura or other species cannot be discarded. Anyway, the wide distribution of the disease and the high rate of symptomatic trees in our region contrast with the low density of the known vectors. Multiplication of infected plant material and root bridges between nearby trees could be also contributing to spread the phytoplasma among and inside orchards, respectively (Ciccotti et al. 2007). In any case, the discovery of other four psyllid species, apart from the known vectors, carrying the phytoplasma reveals that our knowledge on the potential vectors is quite limited and goes far beyond the typical ones. More research is clearly needed to unravel the role 
of the psyllid fauna inhabiting our orchards in the transmission of the phytoplasma as well as to evaluate the influence of the surrounding landscape.

\section{Authors' contributions}

MM conceived and designed research. AS, RR and MM conducted sampling. RR and AS identified species. AM performed phytoplasma detection in psyllids. MM analyzed data and wrote a first draft of the manuscript. All authors read and approved the final manuscript.

\section{Author details}

1 Servicio Regional de Investigación y Desarrollo Agroalimentario (SERIDA), Apdo. 13, E-33300 Villaviciosa, Asturias, Spain. ${ }^{2}$ Instituto de Ciencias AgrariasCSIC, Madrid, Spain.

\section{Acknowledgements}

We thank the growers who allowed us sampling in their orchards. Dr. Daniel Burckhardt provided advice on the identification of some of the psyllid species. We are very grateful to Dr. Rosemarie Tedeschi for her very valuable comments on the manuscript.

\section{Competing interests}

The authors declare that they have no competing interests.

\section{Ethical approval}

This article does not contain any studies with human participants or animals performed by any of the authors

\section{Funding}

This study was funded by the Gobierno del Principado de Asturias, FEDER, Caja Rural de Gijón, CADAE and AACOMASI (Project FICYT PC10-52) and by the Spanish Government and FEDER (Project INIA RTA-2013-00039-C03-01). R. Rosa García and M. Miñarro received grants through the DOC-INIA Program and A. Somoano through the FPI-INIA Program.

Received: 6 April 2016 Accepted: 25 July 2016

Published online: 02 August 2016

\section{References}

Aldaghi M, Massart S, Roussel S, Jijakli MH (2007) Development of a new probe for specific and sensitive detection of 'Candidatus Phytoplasma mali' in inoculated apple trees. Ann Appl Biol 151:251-258

Alma A, Tedeschi R, Lessio F, Picciau L, Gonella E, Ferracini C (2015) Insect vectors of plant pathogenic mollicutes in the Euro-Mediterranean region. Phytopathogenic Mollicutes 5(2):53-73

Baric S, Öttl S, Dalla Via J (2010) Infection rates of natural psyllid populations with 'Candidatus Phytoplasma mali' in South Tyrol (Northern Italy). JuliusKühn-Archiv 427:189-192

Batlle A, Sabaté J, Berra D, Laviña A (2012) Epidemiological study of apple proliferation in Spain. Petria Giornale di patologia delle piante 22(3):176-180

Cainelli C, Forno F, Mattedi L, Grando MS (2007) Can apple aphids be vectors of "Candidatus Phytoplasma mali". IOBC/wprs Bull 30(4):261-266

Ciccotti AM, Bianchedi PL, Bragagna P, Deromedi M, Filippi M, Forno F, Mattedi $L$ (2007) Transmission of 'Candidatus Phytoplasma mali' by root bridges under natural and experimental conditions. Bull Insectology 60(2):387-388

Dapena E, Miñarro M, Blázquez MD (2005) Organic cider-apple production in Asturias (NW Spain). IOBC/wprs Bull 28(7):142-146

Eben A, Gross J (2013) Innovative control of psyllid vectors of European fruit tree phytoplasmas. Phytopathogenic Mollicutes 3(1):37-39

Firrao G, García-Chapa M, Marzachi C (2007) Phytoplasmas: genetics, diagnosis and relationships with the plant and insect host. Front Biosci 12:1353-1375

Foissac X, Wilson MR (2010) Current and possible future distributions of phytoplasma diseases and their vectors. In: Weintraub PG, Jones P (eds) Phytoplasmas: genomes, plant hosts and vectors. CABI, England, pp 309-324
Hansen LO, Hodkinson ID (2006) The mistletoe associated psyllid Cacopsylla visci (Curtis, 1835) (Homoptera, Psyllidae) in Norway. Norw J Entomol 53(1):89-91

Hodkinson ID, White IM (1979) Homoptera: Psylloidea. Handbooks for the Identification of British Insects 2. Royal Entomological Society ofLondon, London, pp 1-98

Irwin ME, Ruesink WG (1986) Vector intensity: a product of propensity and activity. In: McLean GD, Garrett RG, Ruesink WG (eds) Plant Virus epidemics: monitoring, modelling and predicting outbreaks. Academic Press, Sydney, pp 13-33

Irwin ME, Kampmeier GE, Weisser WW (2007) Aphids as Crop Pests. In: Van Emden HF, Harrington R (eds) Aphid movement: process and consequences. CABI Publishing, Wallingford, pp 153-186

Jarausch B, Jarausch W (2010) Psyllid vectors and their control. In: Weintraub PG, Jones P (eds) Phytoplasmas: genomes, plant hosts and vectors. CABI, England, pp 250-271

Jarausch B, Burckhardt D, Lauterer P, Jarausch W (2009) Psyllids (Hemiptera, Psylloidea) captured in commercial apple and stone fruit orchards in southwest Germany, eastern France and northwest Switzerland. Mitt Schweiz Entomol Ges 82(3/4):205-215

Jarausch B, Schwind N, Fuchs A, Jarausch W (2011) Characteristics of the spread of apple proliferation by its vector Cacopsylla picta. Phytopathology 101(12):1471-1480

Kartte S, Seemüller E (1988) Variable response within the genus Malus to the apple proliferation disease. Z Pflanzenkr Pflanzenschutz 95(1):25-34

Laviña A, Sabate J, Batlle A (2011) 'Candidatus Phytoplasmas mali': identification of potential insect vectors in Spanish apple orchards. Bull Insectology 64(Supplement):125-126

Mayer CJ, Jarausch B, Jarausch W, Jelkmann W, Vilcinskas A, Gross J (2009) Cacopsylla melanoneura has no relevance as vector of apple proliferation in Germany. Phytopathology 99(6):729-738

Miñarro M, Prida E (2013) Hedgerows surrounding organic apple orchards in north-west Spain: potential to conserve beneficial insects. Agric Forest Entomol 15:382-390

Miñarro M, Hemptinne J-L, Dapena E (2005) Colonization of apple orchards by predators of Dysaphis plantaginea: sequential arrival, response to prey abundance and consequences for biological control. Biocontrol 50(3):403-414

Miñarro M, Espadaler X, Melero VX, Suárez-Álvarez V (2009) Organic versus conventional management in an apple orchard: effects of fertilization and tree-row management on ground-dwelling predaceous arthropods. Agric Forest Entomol 11:133-142

Oettl S, Schlink K (2015) Molecular identification of two vector species, Cacopsylla melanoneura and Cacopsylla picta (Hemiptera: Psyllidae), of apple proliferation disease and further common psyllids of Northern Italy. J Econ Entomol 108:2174-2183

Olmos A, Cambra M, Esteban O, Gorris MT, Terrada E (1999) New device and method for capture, reverse transcription and nested PCR in a single closed-tube. Nucleic Acids Res 27:1564-1565

Ossiannilsson F (1992) Psylloidea (Homoptera) of Fennoscandia and Denmark. Fauna Entomologica Scandinavica, vol 26. Brill, Leiden

Rosa García R, Miñarro M (2014) Role of floral resources in the conservation of pollinators in cider apple orchards. Agric Ecosyst Environ 183:118-126

Rosa García R, Somoano A, Moreno A, Burckhardt D, de Queiroz DL, Miñarro M (2014) The occurrence and abundance of two alien eucalypt psyllids in apple orchards. Pest Manag Sci 70(11):1676-1683

Strauss E (2009) Phytoplasma research begins to bloom. Science 325(5939):388-390

Tedeschi R, Alma A (2004) Transmission of apple proliferation phytoplasma by Cacopsylla melanoneura (Homoptera: Psyllidae). J Econ Entomol 97(1):8-13

Tedeschi R, Alma A (2006) Fieberiella florii (Homoptera: Auchenorrhyncha) as a vector of "Candidatus Phyoplasma mali". Plant Dis 90:284-290

Tedeschi R, Bosco D, Alma A (2002) Population dynamics of Cacopsylla melanoneura (Homoptera: Psyllidae), a vector of apple proliferation phytoplasma in northwestern Italy. J Econ Entomol 95(3):544-551

Tedeschi R, Visentin C, Alma A, Bosco D (2003) Epidemiology of apple proliferation (AP) in northwestern Italy: evaluation of the frequency of AP-positive psyllids in naturally infected populations of Cacopsylla melanoneura (Homoptera: Psyllidae). Ann Appl Biol 142.285-290 
Tedeschi R, Lauterer P, Brusetti L, Tota F, Alma A (2009) Composition, abundance and phytoplasma infection in the hawthorn psyllid fauna of northwestern Italy. Eur J Plant Pathol 123(3):301-310 Tedeschi R, Baldessari M, Mazzoni V, Trona F, Angeli G (2012) Population dynamics of Cacopsylla melanoneura (Hemiptera: Psyllidae) in Northeast Italy and its roles in the apple proliferation epidemiology in apple orchards. J Econ Entomol 105:322-328
Weintraub PG, Beanland L (2006) Insect vectors of phytoplasmas. Annu Rev Entomol 51:91-111

Zimmermann MR, Schneider B, Mithöfer A, Reichelt M, Seemüller E, Furch AC (2015) Implications of Candidatus Phytoplasma mali infection on phloem function of apple trees. Endocytobiosis Cell Res 26:67-75

\section{Submit your manuscript to a SpringerOpen ${ }^{\odot}$ journal and benefit from:}

- Convenient online submission

\section{- Rigorous peer review}

- Immediate publication on acceptance

- Open access: articles freely available online

- High visibility within the field

- Retaining the copyright to your article 